This PDF is a selection from a published volume from the National Bureau of Economic Research

Volume Title: Trade in Services in the Asia Pacific Region, NBER East Asia Seminar on Economics (EASE), Volume 11

Volume Author/Editor: Takatoshi Ito and Anne O. Krueger, editors

Volume Publisher: University of Chicago Press

Volume ISBN: 0-226-38677-5

Volume URL: http://www.nber.org/books/ito_03-1

Conference Date: June 22-24, 2000

Publication Date: January 2003

Title: Korea's Liberalization of Financial Services Trade

Author: Sang-In Hwang, Inseok Shin, Jungho Yoo

URL: http://www.nber.org/chapters/c10162 


\title{
Korea's Liberalization of Financial Services Trade
}

\author{
Sang In Hwang, Inseok Shin, and Jungho Yoo
}

The financial sector plays a key role in the functioning of a market economy. This was dramatically illustrated by the Asian crisis since 1997. The financial services trade interests us as a subject of international trade and also for its implications on the development of the financial sector.

This paper is about the liberalization of financial services trade in Korea. Following this introduction, section 9.1 briefly reviews the benefits, costs, and risks of the liberalization of financial services trade, as they appear in the literature, and section 9.2 discusses what it takes to realize the benefits of trade in developing countries. Section 9.3 describes Korea's liberalization measures in financial services trade before and after the financial crisis. Section 9.4 discusses the trends in financial services trade in Korea and tries to see what benefits there were from the limited liberalization before the crisis, and section 9.5 concludes the paper.

Among various financial services, the main focus of the paper is on banking services, because banks occupy the central position in Korea's financial sector. Also, two main topics of discussion are two modes of service trade, namely, cross-border and commercial presence, because the other two modes, namely, consumption abroad and the presence of natural persons, are of relatively little importance in the financial services trade. $^{1}$

Sang In Hwang is associate professor at Kangnung National University. Inseok Shin and Jungho Yoo are research fellows at the Korea Development Institute.

1. Mattoo (1999) reports that the financial service trade through commercial presence was two times or more as large as the cross-border trade, whereas the other two modes were insignificant in the case of the United States, the only country that reports trade through commercial presence on a regular basis. 


\subsection{Benefits and Costs of Liberalization of Financial Services Trade}

Banks and other financial service providers offer many different services, such as accepting deposits, lending, underwriting, brokering, and so on, at various rates and fees. In doing so they perform five basic functions, according to Levine (1996): facilitating the exchange of goods and services; facilitating risk management; mobilizing resources; obtaining information, evaluating firms, and allocating capital; and providing corporate control. Obviously, these are critical functions for a market economy, and the externalities involved in the provision of financial services are substantial.

\subsubsection{Benefits of Liberalization}

Liberalization of financial services trade is supposed to provide certain benefits. Better financial services in terms of cost and variety will be offered to domestic customers across the border and by foreign banks that enter the domestic market. Also, as competition intensifies, the domestic banks will be forced to improve the quality and variety of the services while lowering the costs. Consequently, consumers' welfare will increase, and resources previously employed in the financial sector may shift to more productive employment in other sectors, increasing the economy's output under the international price regime. These benefits closely correspond to the gains from trade in the simple model of international goods trade and will be called in this paper the direct benefits.

Liberalization of financial services trade seems to be advocated as much for indirect benefits as for direct ones. The indirect benefits refer to systemic improvements of the financial sector. They include improvements in the basic functions embodied in the banks' services, especially assessment of borrowers' creditworthiness, risk management, and corporate control. In addition, foreign banks are expected to raise the financial sector's standards by which accounts or financial statements are prepared and assets valued, as they follow the home country regulations or international standards (Glaessner and Oks, 1998). The information available about borrowers and, through competition, about financial services providers themselves would also increase in quantity and quality, leading to an improvement of the basic functions.

Also, liberalization of financial services trade can provide an impetus to an improvement in legal and regulatory infrastructure. As financial services trade opens between a developed and a developing country, the banks in both countries would seek to export their services in order to follow and serve their clients. This provides an occasion for the developed country to demand that the developing country's financial regulations and supervision be adequate. The same demand may also come from developing countries' banks, as they seek access to the developed countries' markets. Laws and regulations that have direct bearing on the operations of financial institu- 
tions, such as corporate and bankruptcy law, laws regarding negotiable instruments, and the like, may also improve (Levine 1996).

\subsubsection{Costs and Risks of Liberalization}

Various arguments have been advanced against liberalization of financial services trade. Because few barriers are left in Korea at this moment, as will be explained in section 9.3, some are of little relevance. Examples include the infant industry argument and the argument that too rapid a liberalization could lead to financial distress among domestic financial firms as their profits decline. More relevant would be the argument based on the government's limited ability to properly supervise and monitor a more complex financial system. When combined with the lack of credibility in enforcing prudential regulations and withdrawing (implicit) insurance schemes, the limited ability could encourage banks to take excessive risks at the final expense of the government (Claessens and Glaessner, 1998). This is a risk warranted by the potential for improvements in regulatory infrastructure and strengthening of the government's supervisory capacity.

Other arguments against liberalization seem to be on shaky ground or do not seem strong enough to justify keeping the financial market closed (Musalem, Vittas, and Demirgüç-Kunt 1993). One argument alleges that foreign financial institutions facilitate capital flight out of the host country. However, domestic institutions could play the same role. Another fear is that foreign institutions may drive the local ones out of business and dominate the host country's financial sector. Although this cannot be dismissed as an impossibility, a near or complete domination seems extremely rare. According to Gelb and Sagari (1990), as reported in Levine (1996), foreign banks' median share of total domestic assets in a sample of twenty countries was about 6 percent. A related argument questions the foreign firms' commitment to local markets, worrying about the possibility that they would retreat from the host country in response to difficulties at home or in the local market. Still another argument anticipates difficulty in conducting monetary policy when the presence of foreign institutions is substantial in the financial sector. Claessens and Glaessner (1998) report that in New Zealand, where the financial system is largely in the hands of foreigners, monetary policy is not adversely affected, nor is there evidence of little commitment to the local market.

\subsection{Realization of the Benefits}

This section discusses what it takes for liberalization to succeed in realizing the benefits. The direct benefits are expected to be realized with little difficulty, as in the goods trade, where the gains from trade arise as the goods are delivered across the border. This would be the case for modes of both cross-border trade and commercial presence. 
However, it would not be as easy to obtain the indirect benefits, an improvement of the financial system itself. The reason becomes clear when one recalls the nature of finance. White (1999) says that everywhere finance involves a time-sequencing problem: "Finance always involves an initial conveyance of funds - a loan, an investment - and then a later reversal of the flow of funds - the loan repayment (plus interest), a stream of dividends, etc." (3; author's emphasis). ${ }^{2}$ Even before making a loan, the lender needs to know about the risks and prospects of repayment and, after making the loan, about the borrower's behavior and performance. Information asymmetry exists, however, because the borrower naturally has more information about him- or herself and his or her own work than the lender. If non-repayment is not sanctioned, a moral hazard problem is likely to arise, because the borrower will receive the "upside" benefits from a risky undertaking while not bearing the "downside" costs.

Given these circumstances, financial intermediation evidently requires the basic functions such as information gathering, credit assessment and risk management, and performance monitoring and corporate control. It seems, however, that development of these functions is lacking in many developing countries, including Korea, as the latest Asian financial crises revealed. The lack of development appears to have much to do with the "rules of the game" of a given society. As in North (1990), a society's rules of the game (ROGs) refer to the totality of its formal and informal institutions such as the legal system, government regulations, social customs, and practices. As such, the ROGs refer to the way the written laws and regulations are applied and enforced as well as the laws and regulations themselves. ${ }^{3}$ For our discussion of financial services, one important example of the ROGs would be how the decision is actually made regarding who among many applicants gets the bank loans, and another, what kind of penalty the borrower gets when he or she is unable to pay back the loans.

In Korea and some other Asian countries the government extensively and intensively intervened in the workings of the market through formulating and executing development plans, industrial and trade policies, and socalled administrative guidance. In the process, the banks often became the financing instruments of development plans and industrial policies. The government directly or indirectly exercised influence on loan-making decisions. Under the circumstances, the prospects of repayment or performance may not have been a primary concern to the banks. Also, such government involvement usually carried with it an implicit insurance against losses. In this case, banks had little incentive to develop capacities to perform the basic functions. Moreover, banks themselves were prone to moral

2. The rest of this paragraph also draws on White 1999.

3. Elsewhere, one of the authors provides a fuller discussion of the rules of the game and the importance in Korean context (Yoo 1998). 
hazard, behavior because the owners and managers bore limited responsibilities.

By contrast, development of these capacities will be indispensable if the society's ROGs are fair and transparent. ${ }^{4}$ In this case, borrowers will have equal opportunities to obtain a loan and banks to make loans to prospective borrowers, and it will matter how much profit a bank makes. A lending decision will be evaluated and rewarded in an unbiased manner, mainly on the basis of its consequences on profits, both internally within a bank and externally in the financial market. The banks will do their best in gathering and processing relevant information and in examining the prospect of being repaid the principal and interest. This way, high-quality basic financial functions will be embodied in the services they provide.

Hence, how well developed the basic functions of financial intermediation are in a society would critically depend on the fairness and transparency of its ROGs. The existence of factors of production such as skilled manpower and capital would not be sufficient. In addition, the ROGs in the financial sector should be fair and transparent enough so that high international standards of asset valuation and transparency may be put into practice and effective competition reign in the financial market.

Thus, the realization of indirect benefits of financial services trade will depend on the availability of two different kinds of factors. One may be called internal factors - factors that render services to production by being employed within the firms producing the services in question. Skilled manpower and capital are typical examples. The other may be called external factors, as these render services to production that exist outside firms. In the above discussion such a factor is the society's ROGs. Either one of the two kinds of factors may work as a constraint on the realization of the benefits. Of these two potential constraints, lack or shortage of the internal factors may present less difficulty, because this can be overcome relatively easily at the firm level by training or even by importing from abroad the factors in short supply. However, if unfair and nontransparent ROGs are the binding constraint, the indirect benefits from financial services trade may not be easily realized: What is required is a change in the way the financial market, if not the whole society, operates, although the presence of foreign financial firms may provide an impetus for such a change.

\subsection{Liberalization of Financial Services Trade in Korea}

The need for financial deregulation and reform has long been recognized, but financial deregulation in Korea has been very cautious and slow, as

4. The ROGs are fair when every economic agent enjoys an equal opportunity ex ante and its ability, efforts, and performances are evaluated by the same standard, and when one is held accountable for one's own actions ex post. They are transparent when the rules themselves are known to all economic agents or when a way of knowing them is open to them. 
Kang (2000) reports. Only as recently as early 1997, the same year the country was hit by currency and financial crises, the government established the Presidential Commission for Financial Reform. ${ }^{5}$ The economic crisis brought about fundamental changes to Korea's economic policies. Regarding the policy on financial services trade, the crisis stands as a defining moment. It revolutionized the policy stance from lukewarm and partial opening to swift and full opening. This section begins with a brief review of the exchange rate policy, and the remainder describes the liberalization of financial services trade, distinguishing the precrisis from the postcrisis period.

\subsubsection{Foreign Exchange Rate Policy}

Korea's exchange rate policy changed from a nominal anchor approach in the 1970s to a real target approach with the introduction of Multiple Currency Basket Peg System in February 1980. In the wake of the realignment of major currencies in the mid-1980s, Korea's current account showed large surpluses, and the international financial institutions and the U.S. Treasury accused the Korean government of manipulating its exchange rate. This led to an adoption of Market Average Exchange Rate System in March 1990, under which the won-dollar exchange rate was determined in the market within a band that was initially set at 0.4 percent above and below the rate of the previous day. The band was gradually widened over time and was eliminated in December 1997, immediately after the currency crisis. Since then, the policy maintained a floating exchange rate system and limited government intervention in the exchange market to smoothing volatility.

\subsubsection{Before the Crisis}

\section{Cross-Border Trade}

Before the crisis, the policy on cross-border trade was not made on its own merit but was decided as a by-product of capital account liberalization policy. Specifically, for the banking sector, cross-border trade was not allowed (and still is not) under the banking law, since the law followed positive system and had no provisions regarding cross-border trade. In consequence, only limited cross-border trade was allowed under the Foreign Exchange Management Act as a part of permitted capital transactions.

With respect to capital account liberalization, the policy stance was dictated by the concern about the current account balance. Hence, during the 1990s, when the current account recorded large deficits, the Korean government was reluctant to take any policy measures that would ease capital outflows. 
This policy stance was maintained with regard to the cross-border trade. Liberalization began with those transactions that would lead to capital inflows, although the extent of liberalization was different depending on mode of transactions. Although cross-border trade by individuals was left closed, certain transactions were allowed for corporations as a part of capital account liberalization. Thus, overseas bond issuance by financial institutions and corporations was deregulated in 1991, subject to discretionary quantity control by the government. Also, foreign borrowings by corporations were allowed in 1995, again with attached restrictions on the use of funds and government approval required. Liberalization of trade-related short-term financing was made relatively free, with fewer restrictions attached: regulations on deferred import payments and receipt of advance payments for exports were lifted step by step, with few restrictions throughout the 1990s.

Relative to individuals and corporations, banks were given more freedom in transactions with foreign agents, although the allowed transactions were limited to overseas bond issuing and foreign borrowings. For banks, there were no formal restrictions on foreign borrowings, although it is known that the government imposed informal quantity controls. However, according to practitioners, the restrictions were lifted in 1994.

\section{Commercial Presence}

In the early 1990s when the current account was still in chronic deficit, the government allowed a number of foreign banks to enter the Korean market in order to help attract foreign capital. The government removed the upper ceilings on foreign bank capital in 1991. The five-year financial liberalization plan announced in 1993 aimed mainly at interest rate deregulation and abolition of the limits on maximum maturity for loans and deposits of banks, among other goals. As a part of the liberalization, the scope of financial activities allowed for foreign banks was broadened to include local branch establishment.

Foreign security companies were authorized to do business in 1992, when the Korean stock market was opened partially. Again, however, they were permitted to open only branches.

Regarding commercial presence, a potentially important development occurred in 1996 on Korea's accession to the Organization for Economic Cooperation and Development (OECD). In order to fulfill its obligations as a member of the organization, the Korean government announced in September a blueprint that gradually would remove barriers to foreign portfolio investment and allow foreign direct investment. The following summarizes the 1996 commitments:

- Foreign banks and securities firms from OECD countries would be permitted to establish subsidiaries in South Korea by 1998. 
Table 9.1

Trend in the Expansion of Limits on Equity Investment by Foreigners, 1992-98 (\%)

\begin{tabular}{lcc}
\hline Date & Non-State-Owned Companies & State-Owned Companies \\
\hline January 1992 & 10 & 8 \\
December 1994 & 12 & 8 \\
July 1995 & 15 & 10 \\
April 1996 & 18 & 12 \\
October 1996 & 20 & 15 \\
May 1997 & 23 & 18 \\
November 1997 & 26 & 21 \\
December 1997 & 55 & 25 \\
May 1998 & 100 & 30
\end{tabular}

Source: Financial Supervisory Service, Press Release, January 2000.

- Aggregate foreign investment ceilings for investors from OECD countries were to be phased out by 2000 .

- Foreign investors from OECD countries would be allowed to establish and hold 100 percent ownership of any type of financial institution by December 1998.

- Foreign investment consulting firms from OECD countries would be able to offer their services without establishing a commercial presence in Korea.

\subsubsection{After the Crisis}

Since the economic crisis in 1997, the Korean government has started a sweeping reform of the financial sector. We first take a look at the deregulation of the financial market that allows international transactions of stocks, bonds, and other instruments and then discuss the liberalization of the two modes of financial services trade.

\section{Deregulation of the Financial Market}

Domestic Stock and Bond Market. In order to promote inflows of foreign capital, Korea opened the domestic stock and bond and money markets.

Ceilings on foreigners' equity investments were completely lifted in May 1998 with the exception of investment in state-owned enterprises, as indicated in table 9.1. Also, the requirement was eliminated that domestic subsidiaries of foreign companies should obtain government approval when introducing more than $\$ 1$ million from abroad.

The corporate bond and government bond markets were completely opened to foreigners at the end of 1997, as shown in table 9.2. The foreign investment on the bond of non-listed companies was allowed in July 1998. ${ }^{7}$

7. A more detailed table on bond market liberalization is provided in appendix table 9A.1. 
Table 9.2

Opening of the Bond and Money Markets, 1994-98

\begin{tabular}{ll}
\hline Date & \multicolumn{1}{c}{ Instruments } \\
\hline July 1994 & $\begin{array}{l}\text { Non-guaranteed convertible bonds issued by small and mid-size } \\
\text { companies } \\
\text { Non-guaranteed convertible bonds issued by large companies, and non- } \\
\text { June 1997 }\end{array}$ \\
$\begin{array}{l}\text { guaranteed bonds issued by small and mid-size companies } \\
\text { Fecember 1997 }\end{array}$ \\
$\begin{array}{l}\text { Corporate bond and government bond } \\
\text { CPs 1998 } 1998\end{array}$ & All money market instruments including CDs and Repos \\
\hline
\end{tabular}

Sources: Ministry of Finance and Economy, Press Release, May 1998; Financial Supervisory Service, Press Release, January 2000.

The opening of the money market, such as the markets for commercial papers $(\mathrm{CP})$ and certificates of deposit $(\mathrm{CD})$, proceeded in steps and was completed in May 1998.

Foreign Exchange Market. As of July 1998, the government liberalized medium-term foreign borrowing in order to help the firms attract foreign capital. In addition, the restrictions on the types of goods and duration of credit were also relaxed for import and export credits.

In April 1999, the government abolished the restrictive Foreign Exchange Management Act and replaced it with Foreign Exchange Transaction Act. The regulation for capital account transactions was changed from a positive system to a negative system. As a result, the following capital transactions were allowed:

- Offshore issuance of securities and foreign borrowing with a maturity of less than one year

- Offshore investment in foreign financial markets, foreign insurance markets, and foreign real estate markets by domestic firms and financial institutions

- Establishment of domestic saving deposits (including trust deposits) by nonresidents with a maturity in excess of one year

- Issuance of won-denominated (maturity exceeding one year) and foreign currency-denominated securities by nonresidents, and transactions of derivatives through domestic financial institutions

From the year 2001, foreign exchange transactions by individuals, such as won-based domestic deposits by nonresidents of maturity less than one year, will be liberalized. The government will also allow individuals to freely deposit their money in banks abroad and buy foreign securities or foreign real estate. At this point, the level of liberalization in Korea will be close to that of the OECD countries. 
The Status of Liberalization in 2000

\begin{tabular}{|c|c|c|c|c|c|c|}
\hline & Bank & Security & $\begin{array}{l}\text { Investment } \\
\text { Trust Company }\end{array}$ & $\begin{array}{l}\text { Investment } \\
\text { Advisory }\end{array}$ & $\begin{array}{c}\text { Life } \\
\text { Insurance }\end{array}$ & $\begin{array}{l}\text { Non-Life } \\
\text { Insurance }\end{array}$ \\
\hline Branch establishment & Open & Open & Open & Open & Open & Open \\
\hline $\begin{array}{l}\text { Subsidiary } \\
\text { establishment }\end{array}$ & Open & Open & Open & Open & Open & Open \\
\hline Joint venture & Open & Open & Open & Open & Not open & Not open \\
\hline Cross-border trade & $\begin{array}{l}\text { Partially } \\
\text { open }\end{array}$ & Not open & Partially open & Open & Open & $\begin{array}{l}\text { Aviation, } \\
\text { hull (open) }\end{array}$ \\
\hline
\end{tabular}

Source: Korea Institute of Finance (2000).

\section{Cross-Border Trade}

Despite the sweeping reform and deregulation of the financial sector since the economic crisis, the cross-border trade in the banking sector is only partially opened under the Foreign Exchange Transaction Act, because the banking law, which adheres to the positive system, does not deal with cross-border trade. Also, the cross-border trade in securities is not allowed because the security law allows trading only through commercial presence. However, the investment trust companies (ITC) are allowed to trade mutual funds without commercial presence (see table 9.3).

\section{Commercial Presence}

Important steps were taken in the spring of 1998 to increase foreigners' access to the Korean financial market. Foreign banks and securities firms were authorized to establish subsidiaries in March. In addition, 100 percent foreign ownership of Korean institutions was allowed in April, and foreign nationals were allowed to become directors of Korean banks in May.

Banks. ${ }^{8}$ The branch of a foreign bank is treated as an independent financial institution, and its operations are similar to those of subsidiaries of foreign banks, including retail businesses. There are no restrictions on establishing subsidiaries for foreign banks in Korea. Establishment of a new commercial bank, whether domestic or foreign-owned, requires the permission of only the Financial Supervisory Commission (FSC). The minimum capital required is 100 billion won for establishing a nationwide commercial bank and 25 billion won for a regional bank. In addition, foreign banks in Korea have been able to have local branches in the domestic market since March 1998. The foreign exchange position is regulated for prudential reasons. The maximum oversold position allowed of spot foreign exchange is US\$5 million or 3 percent of capital, whichever is greater. 
Foreign Shares of Domestic Banks as of the end of 1999 (\%)

\begin{tabular}{lcc}
\hline Banks & Government Share & Main Foreign Investor \\
\hline Cho Hung & 80.05 & - \\
Hanvit & 74.65 & - \\
Korea First & 49.00 & New Bridge $(51 \%)$ \\
Seoul & 95.68 & - \\
Korea Exchange & 35.92 & Commerz Bank $(23.6 \%)$ \\
Kookmin & 6.48 & Goldman Sachs $(18 \%)$ \\
Korea Housing and Commercial & 14.50 & ING Group $(10 \%)$ \\
Shinhan & - & Korean-Japanese $(49.43 \%)^{\mathrm{a}}$ \\
KorAm & - & BOA $(16.8 \%)$ \\
Hana & - & IFC $(3.3 \%)$ \\
Peace & - & - \\
\hline
\end{tabular}

Source: Data supplied by Financial Supervisory Service.

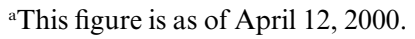

For the ownership of banks, the prior limits of 4 percent in a nationwide bank, 8 percent in a bank converted from a nonbank financial institution, and 15 percent in a regional bank were mitigated by allowing the acquisition of shares in excess of those limits with approval from, or prior notice to, the FSC. Foreign ownership of up to 100 percent was permitted from April 1999, although it is subject to additional review by the FSC in line with the increase in stakes beyond certain predetermined thresholds. Also, laws were enacted to strengthen the powers of banks' boards of directors and to enhance transparency in dealings with shareholders. Foreigners have been permitted to become directors of bank boards since May 1998. Therefore, any foreign bank meeting the conditions, which are applied equally to domestic banks, is allowed to enter the market. ${ }^{9}$

There were sixty one branches of foreign banks and twenty six foreign representative offices as of the end of December 1999. The Korea First Bank was sold in September 1999 to New Bridge Capital in the United States, and there are foreigners participating in management in Housing \& Commercial Bank, HanMi Bank, and Foreign Exchange Bank (see table 9.4).

Nonbank Financial Institutions. In the case of security companies, the foreign investment mostly took the form of opening new branches or offices before the crisis. After the crisis, the foreign investments took the form of acquisition of existing firms or share participation. As of the end of 1999, there were twenty branches of foreign securities companies and seven representative offices in Korea (see table 9.5).

With the removal of entry barriers to the security industry, the efforts to 
Table 9.5

The Trends of Foreign Security Company's Branch, 1991-2000

\begin{tabular}{lccccccccccr}
\hline & 1991 & 1992 & 1993 & 1994 & 1995 & 1996 & 1997 & 1998 & 1999 & 2000 & Total \\
\hline $\begin{array}{l}\text { Establishment } \\
\text { Closure }\end{array}$ & 2 & 5 & 2 & 2 & 4 & 5 & 3 & 2 & 2 & 0 & 27 \\
Total & 2 & 7 & 9 & 11 & 14 & 19 & 22 & 21 & 22 & 20 & 20 \\
\hline
\end{tabular}

Source: Data supplied by Financial Supervisory Service.

Table 9.6 Foreign Participation in Security Firms as of March $2000(\%)$

\begin{tabular}{llr}
\hline Security Company & Main Foreign Investors & Share \\
\hline Seoul & QE International (L) Ltd. & 21.28 \\
& S.A.C. Capital International Ltd. & 3.97 \\
& SR Investment (L) Ltd. & 4.29 \\
& SR Global International Fund LP & 0.44 \\
& Asian Capital Holdings Fund S/A Berceuse Investment N.V & 0.10 \\
Good-Morning & Asia Pacific Growth Fund II & 16.7 \\
& KGRF & 3.6 \\
& Lombard Korea Ltd. & 6.8 \\
Daeyu Regent & Government of Singapore Investment Corp. & 5.9 \\
KEB Smith Barney & Regent Pacific Group Ltd. & 42.68 \\
Hannuri & Saloman Brothers Holding Co., Inc. & 80.00 \\
& Saloman Smith Barney Inc. & 25.00 \\
KGI Cho Hung & Saloman Brothers Holding Co., Inc. & 24.00 \\
Meritz & KGI Korea Ltd. & 51.00 \\
& Trader investment & 30.82 \\
\hline
\end{tabular}

Source: Data supplied by Financial Supervisory Service.

bring in foreign investments led to an increase in capital participation and management participation by foreigners, as shown in table 9.6. In addition, in April 1998, due to the liberalization of security firm establishment, foreign firms' merge with and acquisition of domestic security firms became possible.

\subsection{Trends and Gains in Financial Services Trade in the 1990s}

\subsubsection{Trends in Financial Services Trade}

\section{Cross-Border Trade: Capital Flow}

Policy Stance. As discussed in the previous section, the government pursued financial liberalization throughout the 1990s while varying the speed of liberalization according to concerned economic agents. It seems that the intent was to allow more freedom for banks than for other agents, such as nonfinancial corporations and individuals. Apparently the government preferred gradual liberalization as a way of controlling associated risks and, 
in particular, appeared to have an intention of utilizing banks as a risk manager. Presumably, the underlying assumption was that banks would make cautious brokers in linking foreign suppliers of financial services with domestic consumers, which was proved to be a gross error by the 1997 crisis.

Characteristics. As a result of the government' strategy, the capital flows in and out of Korea during the period took place mainly through the banks. The Korean economy experienced substantial net capital inflows from 1990 through the 1997 crisis. The magnitude of inflows remained small in the first four years, at 1.2 percent of gross domestic product (GDP) on average, but for the three years from 1994 to 1996 more than doubled to 3.5 percent of GDP (see figure 9.1). Stock investment by foreigners explains only the limited portion of the increase, owing to the quantity restrictions imposed. Thus, debt contracts and debt portfolios were the major carriers of capital inflows, and in consequence the surge in net capital inflows was tantamount to a sharp increase in Korea's external debt.

The Korean financial sector was the major issuer of the debt contracts and portfolios. Of the total increase in external debt during 1994-96, the financial sector explains about 70 percent (see table 9.7). As a matter of fact, the amount of resources provided to the Korean banks by foreign creditors was much larger than represented by external debts, as the Korean banks were allowed to open and expand operations of overseas branches as a part of liberalization measures. The resulting increase in borrowings of the overseas branches from foreign banks was as large as the rise in external debts of the Korean banks (see table 9.8).

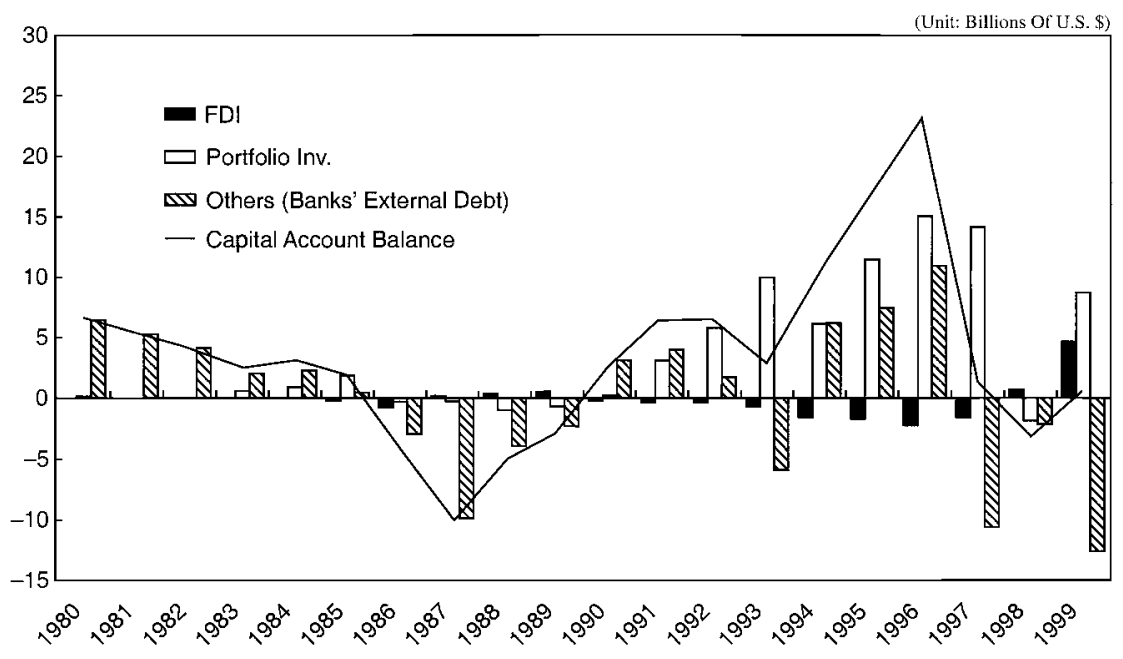

Fig. 9.1 Trend and composition of net capital inflows to Korea

Source: Bank of Korea online service. 
Table 9.7

External Debt of Korea, by Sector: 1992-97 (US\$100 millions)

\begin{tabular}{lrrrrrr}
\hline & 1992 & 1993 & 1994 & 1995 & 1996 & 1997 \\
\hline Public sector & 56 & 38 & 36 & 30 & 24 & 223 \\
Long-term & 56 & 38 & 36 & 30 & 24 & 223 \\
Short-term & 0 & 0 & 0 & 0 & 0 & 0 \\
Corporate sector & 137 & 156 & 200 & 261 & 356 & 462 \\
$\quad$ Long-term & 65 & 78 & 90 & 105 & 136 & 253 \\
Short-term & 72 & 78 & 110 & 156 & 220 & 209 \\
Financial sector & 235 & 244 & 333 & 493 & 667 & 584 \\
Long-term & 122 & 130 & 139 & 196 & 277 & 310 \\
Short-term & 113 & 114 & 194 & 297 & 390 & 274 \\
Total & 428 & 439 & 568 & 784 & 1,047 & 1,268 \\
Long-term & 243 & 247 & 265 & 331 & 437 & 786 \\
Short-term & 185 & 192 & 304 & 453 & 610 & 482 \\
Total/GNP $(\%)$ & 14 & 13.3 & 15.1 & 17.3 & 21.8 & 28.6 \\
\hline
\end{tabular}

Source: Bank of Korea, Annual Foreign Exchange Statistics (various issues); Ministry of Finance and Economy, Press Release, June 8, 1999.

Table 9.8 Foreign Currency Liabilities of Overseas Branches of Korean Banks, 1992-97 (US\$100 millions)

\begin{tabular}{lcccccr}
\hline & 1992 & 1993 & 1994 & 1995 & 1996 & 1997 \\
\hline Domestic branches & 157 & 163 & 226 & 363 & 507 & 387.9 \\
Foreign branches & 201 & 231 & 317 & 413 & 529 & 312.5 \\
Sum & 358 & 394 & 543 & 776 & 1,036 & 700.4 \\
Sum/GNP $(\%)$ & 13.8 & 9.9 & 12.3 & 16.0 & 22.2 & 24.6 \\
\hline
\end{tabular}

Sources: Bank of Korea, Annual Foreign Exchange Statistics (various issues); Korea Development Institute, Major Indicators of the Korean Economy (various issues).

As is well known, creditors to the Korean banks were foreign banks. Hence, we can sum up that the cross-border financial services trade of Korea for the 1990s had been mainly between Korean banks and foreign banks. Transactions involving final consumers remained limited.

\section{Commercial Presence}

Policy Stance. Throughout the 1990s the Korean government continued to be reluctant to allow wider commercial presence of foreign financial institutions, as discussed in the previous section. As a result, the only form of entry into the Korean financial market permitted to foreign banks was the opening of branches.

It was noted earlier that the Korean government preferred banks' acting as risk manager in allowing more inflow of foreign capital and in its allocation. The conservative policy stance toward commercial presence may be explained by the same preference. The rationale must have been that, for the banks to fulfill the job properly intended for them, they needed to be pro- 
tected from too much protection, which might hamper their soundness. Thus, commercial presence of foreign banks could not be encouraged.

In addition, the policy stance seems to have been strongly influenced by a development in the domestic market that adversely affected the banking sector. Since the 1970s, the Korean government promoted the development of securities markets. Naturally it led to the rapid growth of such players as investment trust companies and merchant banking corporations. ${ }^{10}$ That the Korean banks were already facing tough competition from non-banking financial institutions deterred any policy initiatives that might further increase hardship for the Korean banks.

Characteristics. Given the policy stance, the opening of branches of foreign banks in the 1990s was sluggish, to say the least. The number of branches in operation actually declined. In addition, their market share compared to the Korean banks shrank (table 9.9, figure 9.2).

Not only their overall growth but also their scope of business was confined. Among sources of funds for the foreign banks, interoffice borrowing dominated, accounting for over 70 percent of their liabilities. The rest of liabilities were in the form of offshore borrowing (figure 9.3). Reflecting the liability side, foreign currency-denominated lending was the major component of their assets. In particular, the Korean banks were the main borrowers (figure 9.4).

In sum, until the financial crisis, the financial services trade through commercial presence was not much different from cross-border trade. It was only facilitating capital inflows into the Korean economy rather than allowing foreign intermediaries to participate fully in the Korean financial market.

\subsubsection{Gains from Trade?}

The experience with financial services trade in Korea during most of the 1990s was limited in both the scope of trade liberalization and the length of time. This subsection first tries to see if direct benefits of better financial services were provided and then discusses whether there were any direct benefits of systemic improvement in the financial sector.

\section{Direct Benefits}

Liberalization of financial services trade is supposed to provide better financial services in terms of cost and variety and increased output through resource reallocation. We observe the trend in interest rate margin between banks' lending and borrowing rates, because it is relatively straightforward compared to measuring the improvement in variety or estimating the increase in the nation's output. 


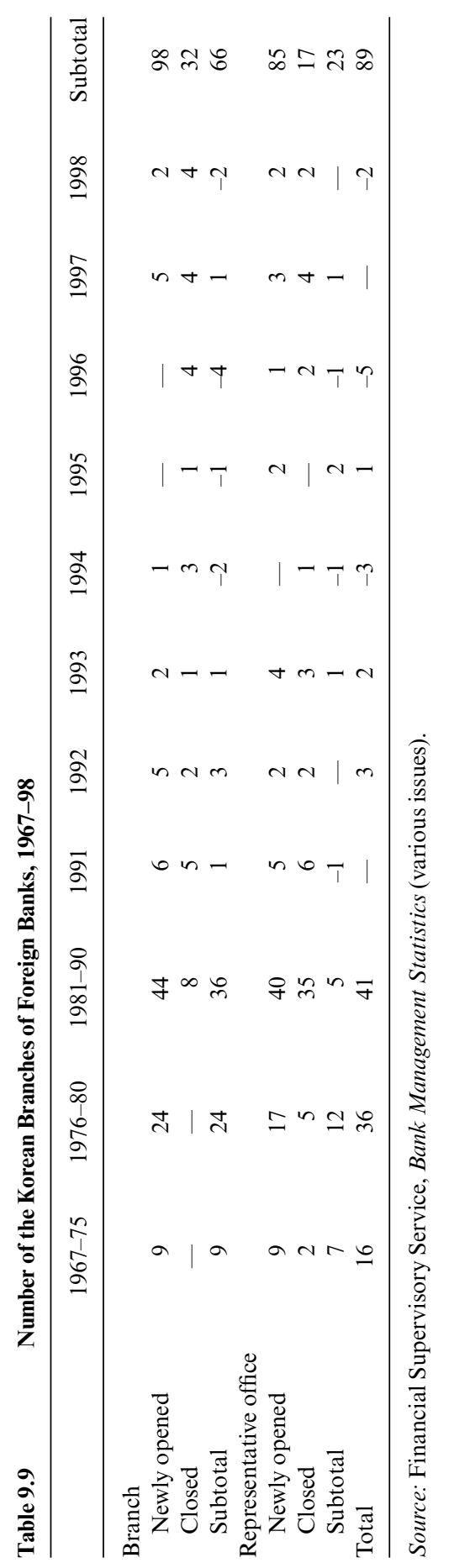




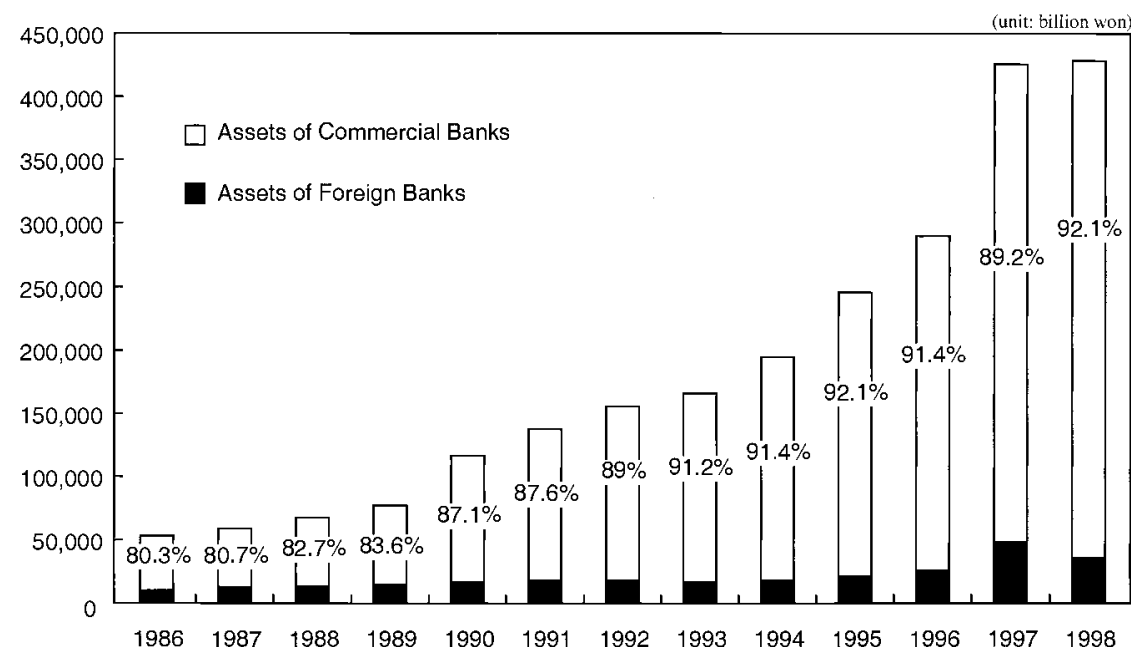

Fig. 9.2 Growth in assets of the Korean branches of foreign banks (in comparison to Korean banks)

Source: Financial Supervisory Service, Bank Management Statistics (various issues).

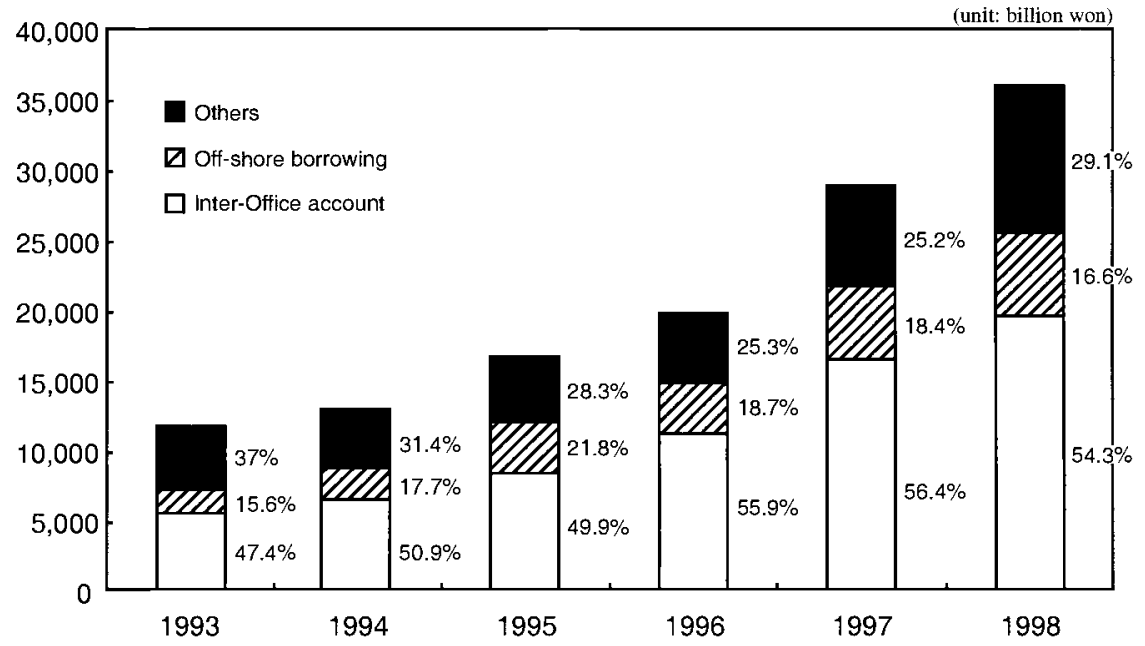

Fig. 9.3 Liability composition of the Korean branches of foreign banks

Source: Financial Supervisory Service, Bank Management Statistics (various issues).

The interest margins appear to decline in the 1990s (see table 9.10). When computed by subtracting deposit rate from lending rate, the average over the five years from 1992 to 1996 was 2.60 , representing a 27 percent decline from the average margin over the preceding five years of 3.58. Moreover, this may underestimate the actual drop, because the interest rates were un- 


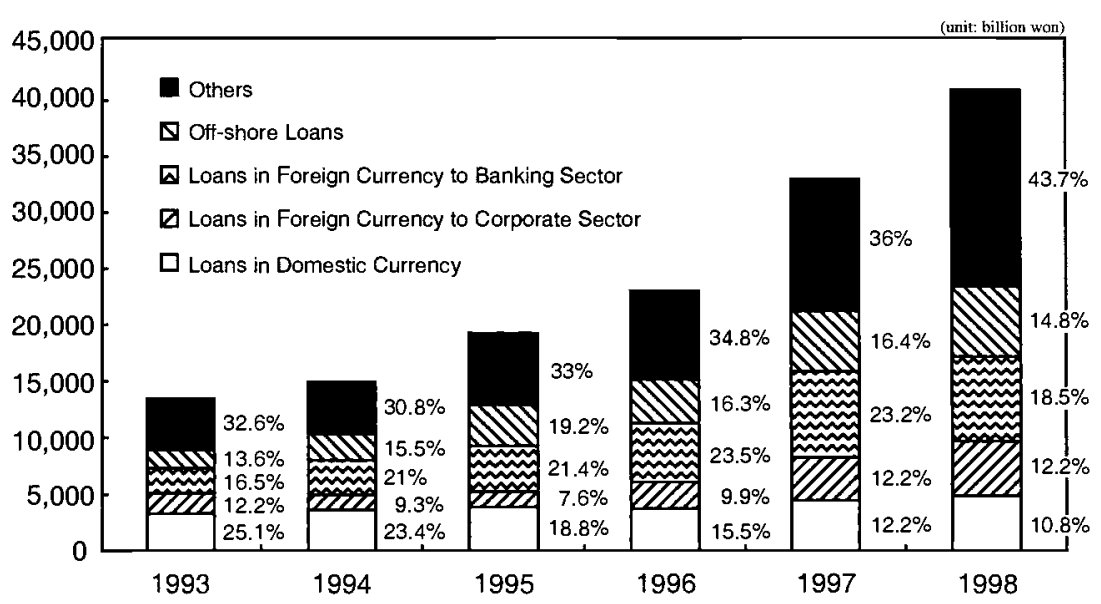

Fig. 9.4 Asset composition of the Korean branches of foreign banks

Source: Financial Supervisory Service, Bank Management Statistics (various issues).

der the influence of the government. It should be noted that, despite interest rates' deregulation in the 1990s, banks were not given full freedom to adjust the lending rates. Through moral suasion, the policy makers effectively depressed banks' "official" lending rates as well as deposit rates. As is well known, banks got around this informal control when providing loans by demanding that borrowers deposit some portion of the loans at low interest rates. If the corporate bond rates are used as proxy for the bank lending rates in computing the margins, the magnitude of decline exceeds 40 percent. The cost of capital, when based on corporate bond rates, was clearly declining as well.

However, it does not seem appropriate to attribute these developments to liberalization of the financial services trade alone. Liberalization of domestic financial markets was also under way. Moreover, the scope of financial services trade liberalization before the financial crisis was rather limited, as noted earlier.

\section{Two Hypotheses Regarding Indirect Benefits}

Did the Korean economy then obtain some benefits of systemic improvement in the financial sector from the limited liberalization in the 1990s? Hypothetically, we think there could be the following two benefits.

First, there might be gain from better monitoring. We noted that most financial services trade took place between Korean banks and foreign banks. With this, it should be noted that Korean depositors or creditors to the Korean banks did not perform much of a monitoring function on their banks, since they felt safe under the implicit insurance provided by the govern- 


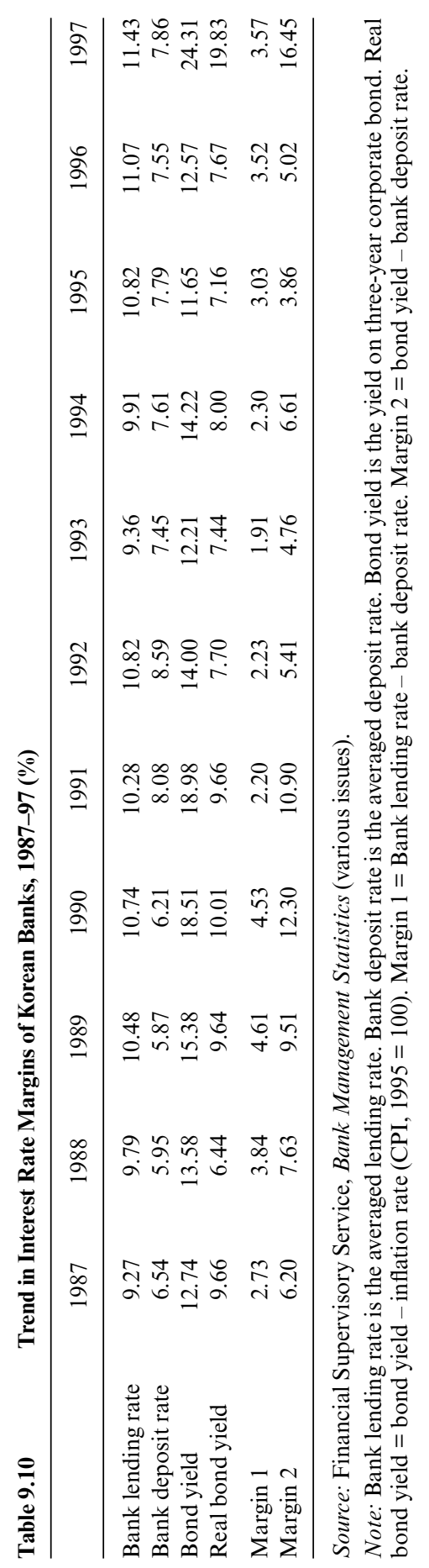




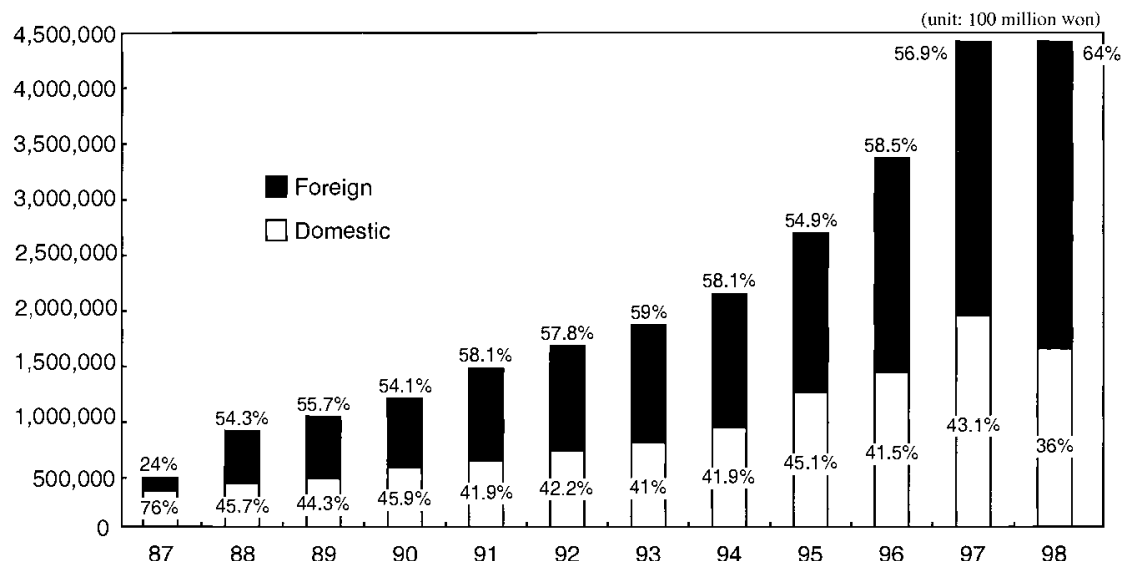

Fig. 9.5 Composition of total assets of Korean banks, by currency

Source: Financial Supervisory Service, Bank Management Statistics.

ment. Given the situation, if foreign banks played a market disciplinary role as large creditors, it could be regarded as a systemic improvement of the financial sector.

Second, it is possible that the Korean branches of foreign banks may have played a stabilizing role during the currency crisis. A low local commitment is often pointed to as a risk that might accompany financial liberalization: When crisis hits a country, foreign creditors tend to rush out of the country, leaving domestic companies in a severe foreign currency credit crunch. This would be more likely if creditor-borrower relationships are maintained at arm's length. By contrast, commercial presence of foreign banks might ameliorate the problem because they might then be more committed to relationship banking.

We examine these hypotheses in turn.

Was There Better Monitoring? ${ }^{11}$ If foreign banks supplied credit to Korean banks with monitoring, it would have had a rather strong disciplinary effect on Korean banks. Throughout the 1990s more than half of the assets held by Korean banks were in foreign currencies (figure 9.5), and Korean banking regulations prohibited banks from taking net open currency position. Thus, a decrease in the supply of foreign credit would have implied a significant reduction in the opportunity set for asset management.

In order to see if foreign creditors performed any monitoring function, we investigate whether their lending behavior could be explained in terms of creditworthiness of individual Korean banks. If they did monitor Korean banks, we may argue, it should be reflected in their credit policy toward the Korean banks. 


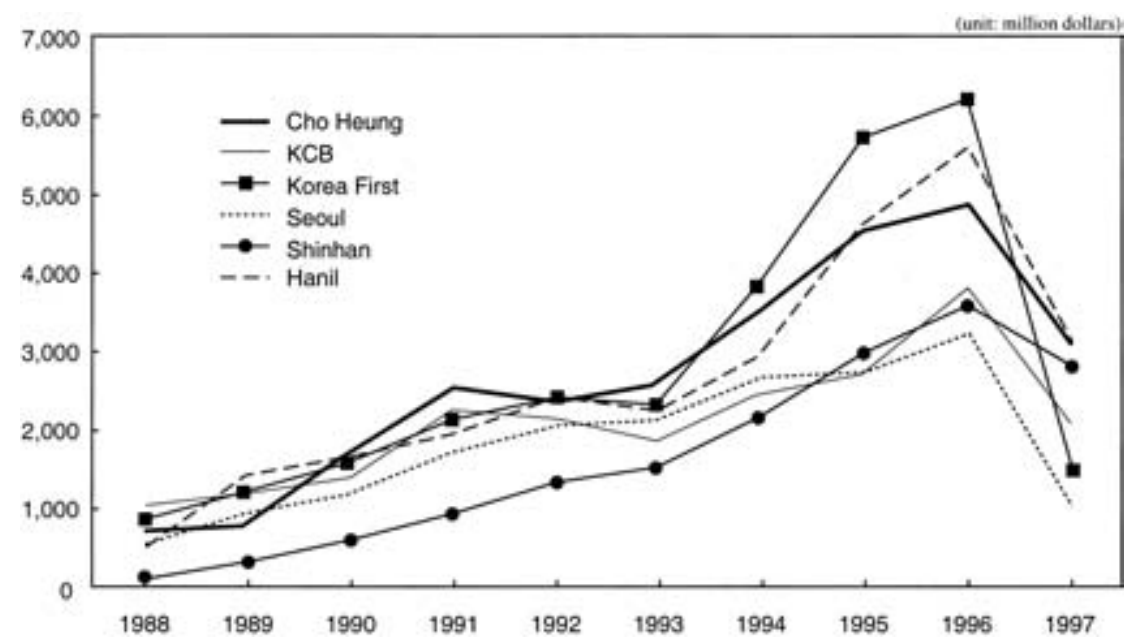

Fig. 9.6 Growth of foreign currency liabilities of the six largest Korean banks Source: Cho Heung, KCB, Korea First, Seoul, Shinhan, Hanil Bank.

The trend in foreign currency liabilities of the six largest commercial banks in Korea is shown in figure 9.6. As is evident in the figure, all of the banks were increasing their foreign currency liabilities throughout the 1990s. Also evident, however, is an acceleration in the growth rates for the three years from 1994 to 1996 and a sharp drop afterward in 1997. Our examination is focused on development for the 1994-96 period.

Although faster growth than in previous years is common to all six banks, we note two banks, in particular: the Korea First Bank and Seoul Bank. These two banks turned out to be the most troubled banks during and after the crisis development. Capital of both banks was found to be completely eroded, so the government was forced to intervene in December 1997 by injecting public money. However, despite the similarity in terms of capital soundness, in foreign currency liabilities the two banks displayed quite contrasting trends. The Korea First Bank recorded the highest growth rate, whereas Seoul Bank recorded the lowest by a considerable margin. It is questionable, however, if the inability of Seoul Bank to expand foreign currency operation was due to foreign creditors' monitoring. Rather, the bank's expansion was constrained by the supervisory authority. Although there was much to be desired in Korean banking supervision, we are informally told that even under the less-than-satisfactory supervision practice, the supervisory authority considered Seoul Bank to be in serious trouble and felt it necessary to impose discretionary restrictions on its operation. In other words, it appears that in the case of Seoul Bank a different kind of monitoring may have been in operation.

As a way of tentatively gauging whether the individual creditworthiness 
Table 9.11

Relationships of Foreign Currency Liabilities of Korean Banks with Other Financial Variables (\%)

\begin{tabular}{|c|c|c|c|c|c|c|}
\hline & $\begin{array}{c}\text { Growth } \\
\text { Rate }\end{array}$ & ROA & ROE & $\begin{array}{l}\text { Stock Price } \\
\quad \text { (won) }\end{array}$ & $\begin{array}{c}\text { Capital } \\
\text { Ratio }\end{array}$ & $\begin{array}{l}\text { Net Worth } \\
\text { Ratio }\end{array}$ \\
\hline Cho Heung & 2.78 & 0.41 & 5.98 & 9,701 & 3.23 & 6.52 \\
\hline $\mathrm{KCB}$ & 4.43 & 0.30 & 4.80 & 7,841 & 3.54 & 6.23 \\
\hline Korea First & 5.77 & 0.18 & 2.85 & 8,588 & 3.03 & 6.86 \\
\hline Seoul & 1.19 & -0.14 & -2.09 & 6,937 & 4.23 & 6.84 \\
\hline Shin han & 2.25 & 0.72 & 7.76 & 15,702 & 3.32 & 9.65 \\
\hline Han Il & 5.98 & 0.33 & 4.80 & 9,067 & 3.36 & 7.33 \\
\hline Correlation & & 0.7479 & 0.2411 & -0.224 & -0.6298 & -0.2592 \\
\hline Coefficient & & $\begin{array}{c}0.13 \\
(0.28)\end{array}$ & $\begin{array}{c}0.522 \\
(3.48)\end{array}$ & $\begin{array}{c}-0.0001 \\
(0.0003)\end{array}$ & $\begin{array}{c}-2.96 \\
(1.82)\end{array}$ & $\begin{array}{c}-0.41 \\
(0.77)\end{array}$ \\
\hline Correlation $^{2}$ & & -0.8255 & -0.8668 & -0.7051 & -0.1542 & -0.4697 \\
\hline Coefficient $^{2}$ & & $\begin{array}{l}-6.91 * * \\
(2.73)\end{array}$ & $\begin{array}{c}-0.81 * * \\
(0.27)\end{array}$ & $\begin{array}{c}-0.0003 \\
(0.0002)\end{array}$ & $\begin{array}{c}-1.41 \\
(5.19)\end{array}$ & $\begin{array}{c}-0.58 \\
(0.63)\end{array}$ \\
\hline
\end{tabular}

Source: Bank of Korea, Bank Management Statistics (various issues).

Notes: Growth rate $=1993-96$ growth rates of foreign currency liabilities $\div 1990-93$ growth rates of foreign currency liabilities. Capital ratio $=$ capital stock $\div$ total assets. Net worth ratio $=$ shareholder's equities $\div$ total assets. Coefficient is computed by regressing growth rates on each variable. Correlation ${ }^{2}$ and coefficient $^{2}$ are after excluding Seoul Bank. Numbers in parentheses are standard deviations.

**Significance at the 5 percent level (d.f. $=4)$.

of Korean banks was one of the determinants for credit policies of foreign banks, we now compute correlation of the growth rates of six banks with their various performance and capital soundness variables. In particular, keeping the above information in mind, we do the same calculations with two sets of banks, one including all of the six banks and the other including all but Seoul Bank.

Inspecting the result, shown in table 9.11, we note the following. First, when Seoul Bank is included, the growth rate of foreign currency liabilities is not significantly related with any variable considered. In addition, it has negative, albeit insignificant, relationships with capital variables. Second, when Seoul Bank is excluded, negative relationships of the growth rate with all the variables are estimated. Moreover, the relationships with performance variables are statistically significant at the 5 percent level, although the degree of freedom was low at 4 .

Therefore, albeit tentatively, overall evidences are against the hypothesis that foreign banks were monitoring and concerned about the creditworthiness of individual Korean banks. ${ }^{12}$

12. Surely it begs an answer why there seem to be negative relationships between foreign currency liabilities and their creditworthiness. Dooley and Shin (2000) argue that it reflects incentives for Korean banks to exploit the value of implicit insurance by the government. Also, one may wonder how foreign creditors were pricing their loans to Korean banks. Unfortu- 


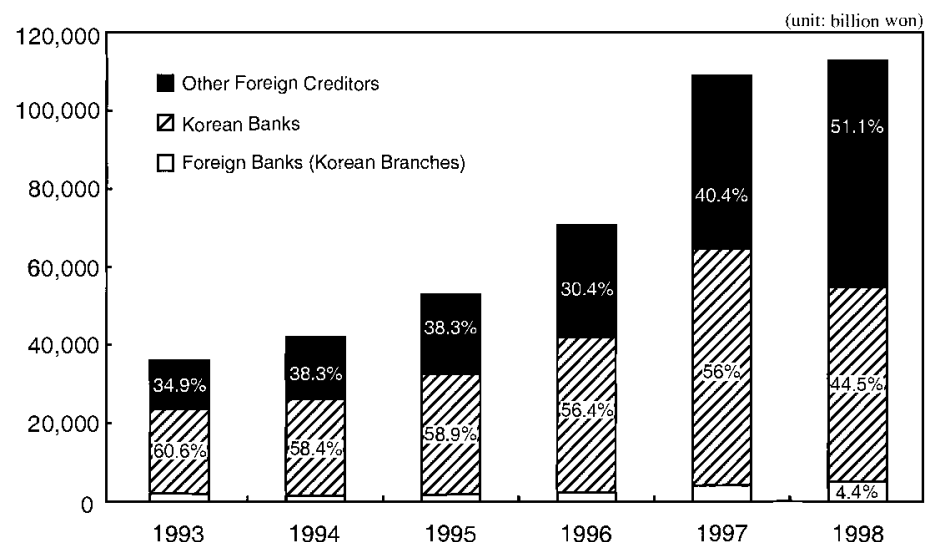

Fig. 9.7 Loans in foreign currency to corporate sector

Source: Financial Supervisory Service, Bank Management Statistics, various issues; Bank of Korea, Annual Foreign Exchange Statistics (various issues); Ministry of Finance and Economy, press release, 8 June 1999.

Did Commercial Presence of Foreign Banks Mitigate the Credit Crunch? In evaluating the hypothesis on a possible stabilizing role of Korean branches of foreign banks, our answer relies on the following two observations.

First, as shown in figure 9.2, of the total assets held by banks, including both domestic and foreign currency assets, the share of Korean branches of foreign banks changed little after the crisis. If anything, their share decreased a bit in 1998. Hence, based on the changes in total assets, it is hard to argue that Korean branches of foreign banks played a mitigating role in the crisis. Second, narrowing the focus to foreign currency credit to the corporate sector, the share of Korean banks declined and that of the Korean branches of foreign banks increased slightly after the crisis (figure 9.7). This tends to indicate that commercial presence of foreign banks mitigated the crisis. However, their share was too small to be of any material impact. Besides, "other foreign creditors" who provided credit at arm's length also increased their share. Thus, compared to these "other foreign creditors," the commercially present foreign banks do not appear to have played any greater role. Therefore, overall it is hard to conclude either that the commercial presence of foreign banks in Korea rendered soothing effects during the crisis or that it did not.

nately, no official data on borrowing rates of individual Korean banks exist. Nonetheless, we are informed by Bank of Korea officials that there was not much discrepancy among Korean banks in terms of international borrowing rates. Finally, as noted by one anonymous referee, the exercise would remain incomplete unless determinants of bank-level foreign currency balances are identified. Therefore, the result of the exercise needs to be taken cautiously. 


\section{Discussions}

Why Were the Gains from Financial Services Trades Not Evident? In theory, international trade "without distortion" is supposed to increase the welfare of the countries engaged. Thus, given the result that financial services trades did not seem to be welfare improving for Korea before the crisis in 1997, naturally we come to ask what kind of distortions existed. In our view, the answer is obvious: the presence of insured agents and uneven liberalization tilted toward those transactions with insured agents, namely, the banks.

Banks in Korea have been under implicit insurance, as in most other economies. Thus, unless other preventive mechanisms are provided, counterparties of Korean banks in transactions are likely to have incentives to take advantage of insurance. What we have shown is that foreign banks were not exceptions. In addition, by regulation Korean banks were the only effective channels through which financial services trade took place. This, together with the incentives given to foreign banks, implies that most of the financial services trades for Korea were likely to be affected by distortion of insurance.

In retrospect, therefore, one should not be surprised to find that financial services trade brought about little gain to the Korean economy.

Are There Ways to Improve the Situation? The logical remedy to the problem would be to remove the insurance. As has been proven in other countries and by historical episodes, however, it is easier said than done. In fact, some public insurance for banks would be practically unavoidable.

In the presence of certain insured transactions, policy responses to exploit gains from trades should be twofold: regulation and close supervision of insured transactions and liberalization of uninsured transactions. Insured transactions need to be monitored by the insurance provider in order to moderate moral hazard, which is the basic teaching of microeconomics. In the case of financial services trades, it simply points to the necessity of prudential regulation and supervision of banks. While keeping insured transactions under close monitoring, one can make the most gains from trades by allowing relatively free trade of uninsured transactions. It implies that the commercial presence of foreign financial institutions should be more liberalized to obtain gains from trades.

That said, we realize that improved supervision of banks and a more liberalized regime for commercial presence was exactly the policy strategy taken by the Korean government after the 1997 crisis. Thus, as far as the Korean case is concerned, we shall see in the near future if the policy change proves to be sufficient to receive benefits from the liberalization of financial services trade.

\subsection{Conclusion}

Perhaps it is too early to make a comprehensive assessment of the impact of the liberalization of financial services trade, because many of the liberal- 
ization measures currently in place have been taken only after the financial crisis in 1997. Korea's liberalization commitment was rather limited at the conclusion of the Uruguay Round negotiation on financial service in December 1997 (Mattoo 1999). As was mentioned in section 9.3, in 1996 on its accession to the OECD Korea made a substantial commitment to financial reforms and liberalization that were going to be gradually implemented. After the financial crisis, this commitment was bound in the context of the World Trade Organization (WTO), and the reforms and liberalization were quickly carried out. Therefore, the liberalization could not have had much impact, since the variety of financial services to be traded had been rather limited and agents allowed to trade had also been restricted before the crisis, and not enough time has passed after the crisis.

As was discussed in the previous section, the liberalization of financial services trade before the crisis led to a substantial capital inflow via the cross-border mode of trade. Trade via the commercial presence mode also took place, and this also mainly led to an increase in capital inflow, because the main source of the funds of the foreign banks was interoffice borrowing and their main clients were Korean banks. Hence, it was little different from the cross-border mode.

Freer capital flows have the effect of smoothing consumption over time, and this has to be recognized as the benefit of the liberalization. Of greater interest to Korea, however, especially in the aftermath of the financial crisis, would be the quality of five basic functions embodied in the services that foreign banks provide. Section 9.4 considered whether foreign banks played any disciplinary role through better monitoring, given that Korean banks were under government-provided implicit insurance. There was little evidence of such a role. On the contrary, the growth of their lending during the 1990s to domestic banks and a statistically significant, negative correlation with indicators of the banks' performance.

However, it would be too hasty to conclude that liberalization does not provide the benefits discussed in section 9.2. Unlike trade in goods, from which the benefits more or less automatically flow as the goods are delivered across the border, the benefit from services trade is not automatic. The quality of financial services, especially that of the basic functions embodied in the services, depends very much on the ROGs in the domestic financial sector, as discussed in section 9.3. Unless the ROGs become fair and transparent so that information gathering, credit assessment, risk management, and so on may be the essential part of financial intermediation, it seems that liberalization cannot deliver the indirect benefits. The finding in section 9.4 seems to be evidence of this point.

Section 9.4 also examined whether the commercial presence of foreign banks mitigated (foreign currency) credit crunch during the crisis. Related to this was the question of whether foreign banks tend to have low local commitment and flee at the first sign of difficulty in the local economy. No strong evidence was found either for the mitigating role or for low local 
commitment. However, since the commercial presence of foreign banks in the financial sector was rather limited, the discussion can only be tentative, and no firm conclusion is warranted from Korean experience regarding the effect of the commercial presence.

After the financial crisis, the Korean government drastically widened the scope and quickened the pace of liberalization and carried out reforms, making efforts to rehabilitate the financial sector, strengthening the prudential regulation, and revamping the supervisory infrastructure. This represents a renouncement of its policy on the financial sector before the crisis, the policy that gave rise to "implicit insurance," as discussed in section 9.4. A crucial question for the success of financial reform is whether the renouncement will be adhered to, because the government's strong influence on the financial sector was one of the major factors underlying the crisis. A related development in the process of managing the crisis is that the influence of the government on the financial sector has become stronger after the crisis. It remains to be seen if the government sticks to the renouncement of its past policy, despite its strengthened influence. 


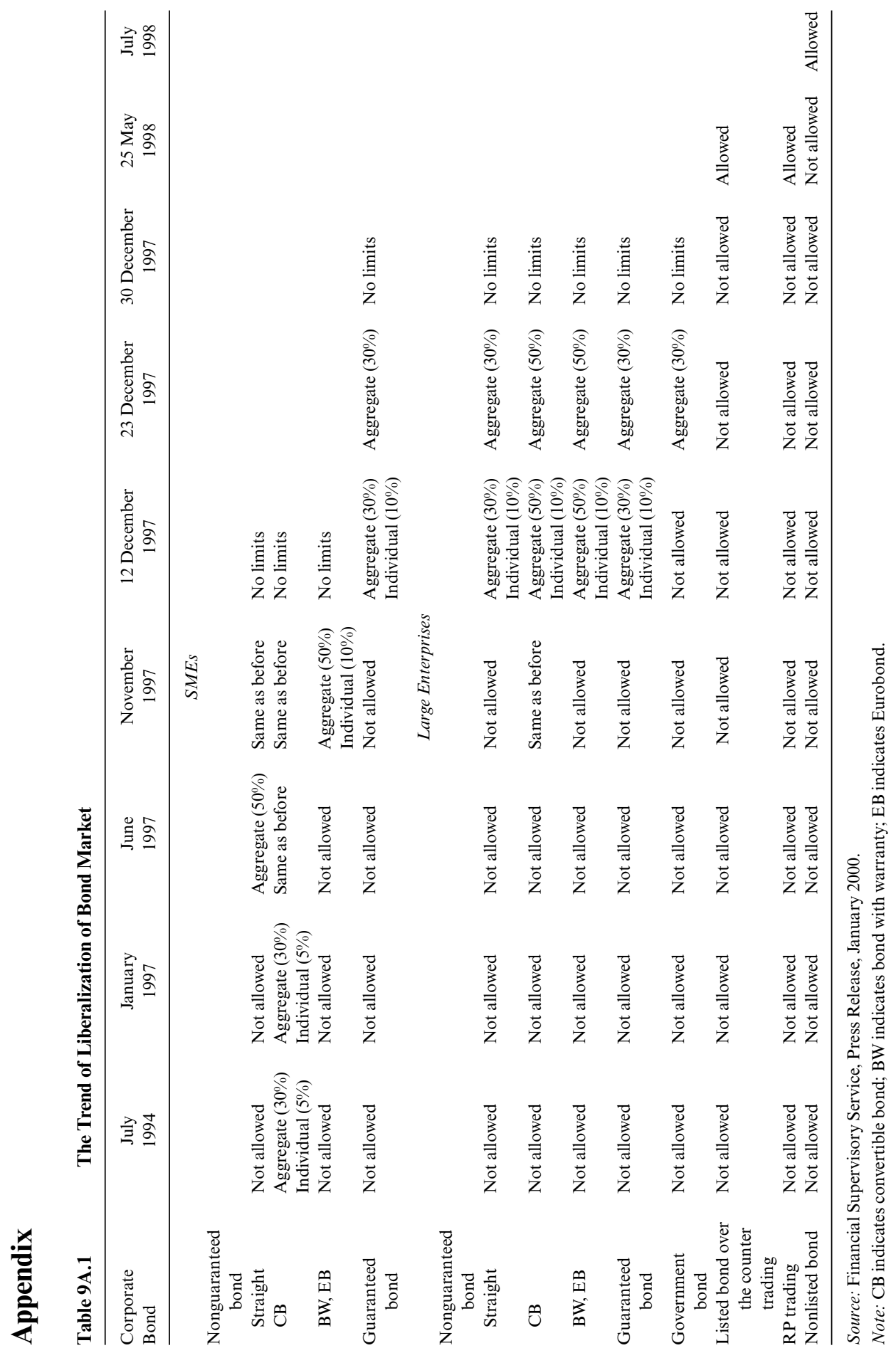




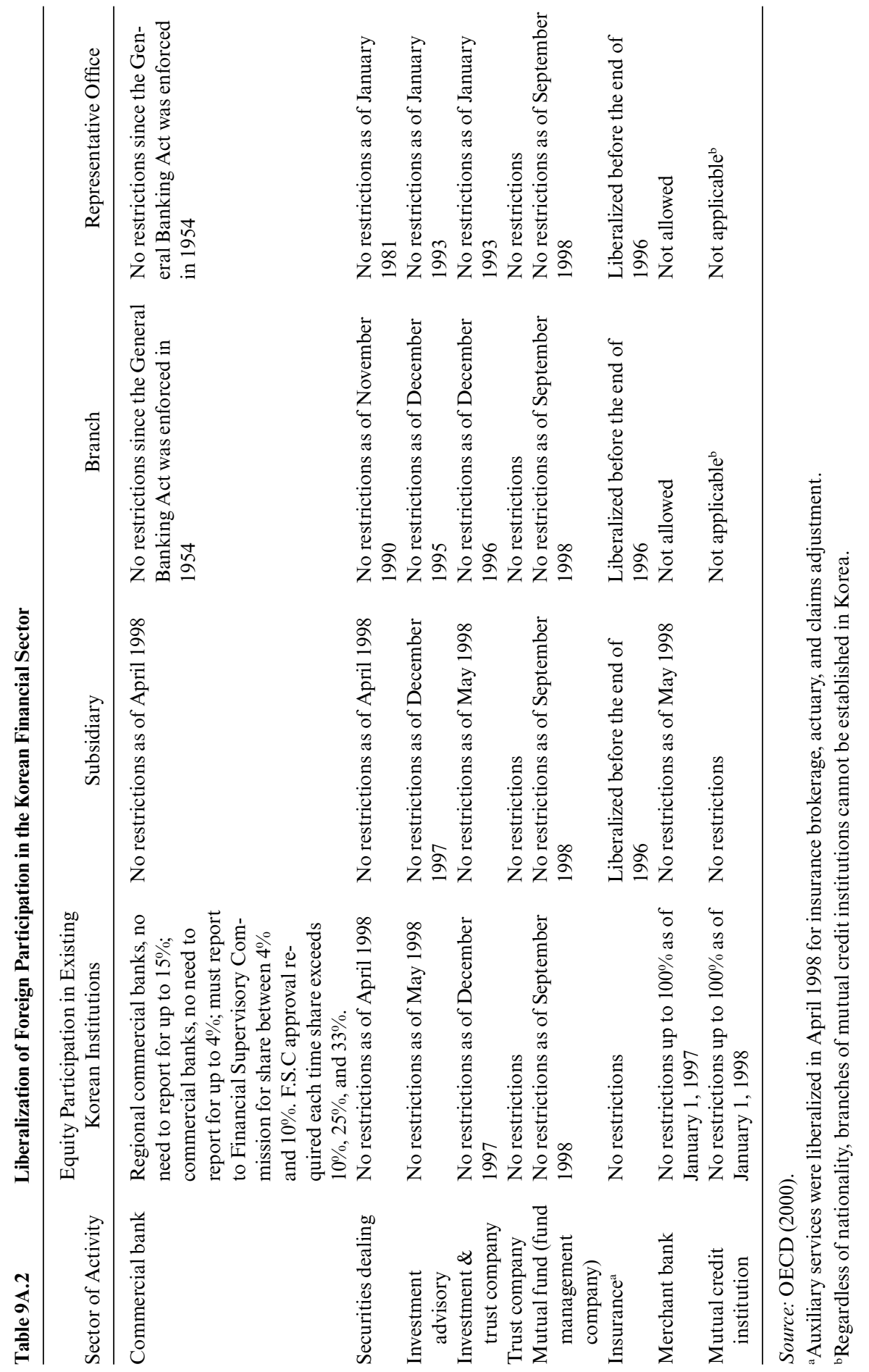




\section{References}

Bank of Korea. Various issues. Annual Foreign Exchange Statistics (in Korean). Seoul: Bank of Korea.

Claessens, Stijn, and Thomas Charles Glaessner. 1998. Internationalization of financial services in Asia. World Bank Policy Research Working Paper no. WPS 1911. Washington, D.C.: World Bank.

Dooley, Michael P., and Inseok Shin. 2000. Private inflows when crises are anticipated: A case study of Korea. In The Korean crisis: Before and after, ed. Inseok Shin, 145-82. Seoul: Korea Development Institute.

Financial Supervisory Service. Various issues. Bank Management Statistics (in Korean). Seoul: Financial Supervisory Service.

Glaessner, Thomas Charles, and Daniel Oks. 1998. NAFTA, capital mobility, and Mexico's financial system. World Bank Policy Research Working Paper no. WPS 1984. Washington, D.C.: World Bank.

Gelb, Alan H., and Silvia B.. Sagari. 1990. Banking. In Uruguay Bond: Services in the world economy, ed. P. Messerlin and K. Savant, 49-59. Washington, D.C.: World Bank.

Kang, Moon-Soo. 2000. Financial deregulation and competition in Korea. In Deregulation and interdependence in the Asia-Pacific region, ed. Takatoshi Ito and Anne O. Krueger, 277-303. Chicago: University of Chicago Press.

Korea Institute of Finance. 2000. Main issues in international financial markets (in Korean). Department of International Finance. Mimeograph.

Levine, Ross. 1996. Foreign banks, financial development, and economic growth. In International financial markets, ed. Claude E. Barfield, 224-54. Washington, D.C.: AEI Press.

Mattoo, Aaditya. 1999. Financial services and the World Trade Organization: Liberalization commitments of the developing and transition economies. World Bank Policy Research Working Paper no. WPS2184. Washington, D.C.: World Bank, September 30.

Musalem, Alberto, Dimitri Vittas, and Alsi Demirgüç-Kunt. 1993. North American free trade agreement. World Bank Policy Research Working Paper no. WPS1153. Washington, D.C.: World Bank.

North, Douglas. 1990. Institutions, institutional changes, and economic performance. Cambridge: Cambridge University Press.

Park, Won-Am. 1996. Financial liberalization: The Korean experience. In Financial deregulation and integration in East Asia, ed. Takatoshi Ito and Anne O. Krueger, 247-76. Chicago: University of Chicago Press.

Organization for Economic Cooperation and Development (OECD). 2000. Korea: Examination of position under the codes of liberalization and the declaration and decisions on international investment and multinational enterprises. OECD Document no. DAFFE/INV/IME(99)2/REV2.

White, Lawrence J. 1999. The role of financial regulation in a world of deregulation and market forces. Paper presented at IMF Conference, Second-Generation Reforms. 8-9 November, Washington, D.C.

Yoo, Jungho. 1998. The nature of the national economy in a borderless world and the role of the government. In Korea's choices in emerging global competition and cooperation, ed. L. Cho and Y. Kim, 65-95. Seoul: Korea Development Institute. 


\section{Comment Kazumasa Iwata}

This paper is very useful in assessing the process of liberalization in trade in financial services in Korea. Its analysis centers on cross-border trade and the mode of trade via commercial presence. The financial liberalization was triggered and promoted by Korea's accession to the Organization for Economic Cooperation and Development (OECD) in 1996. To my surprise, it has been accelerated by the financial and currency crisis of 1997 .

The authors put emphasis on the importance of high performance of basic functions of financial intermediaries via commercial presence and the improvement of Hayekian legal and regulatory infrastructure (or the "rules of the game" of a given society), aside from the better quality and variety of services provided by foreign institutions. However, they fail to confirm the hypothesis on the expected improvement in regulatory infrastructure; the financial crisis seems to have distorted and prevented the effect of trade in financial services from fully realizing in the economy. However, they testify to the effect of distorted liberalization based on Dooley's hypothesis on insurance models of financial crisis (Chinn, Dooley, and Shresta 1999).

The paper noted that in the 1990s cross-border trade in financial services was largely carried out between Korean banks and foreign banks. Notably, before the crisis the Korean banks were mainly borrowers. Partly due to the regulations on open currency position, the borrowing of overseas branches from foreign banks was as large as the external debt of the Korean Banks. On the other hand, the trade through commercial presence was not much different from cross-border trade, given the limited business scope for foreign banks.

It is indeed interesting to observe that foreign banks as lenders to Korean banks are not concerned about creditworthiness and did not play the disciplinary role of monitoring the individual Korean banks (table 9.11). The increase in borrowing from foreign banks tends to lower the rate of return on assets of the Korean banks. The empirical evidence seems to support the hypothesis on implicit insurance by the government and looting the value of insured assets by foreign and Korean banks (Dooley's insurance model on financial crisis). The insurance model also assumes that the capital flight of uninsured assets will emerge before the crisis and peak at the time of crisis. This paper finds no strong evidence on capital flight through foreign financial intermediaries, as compared with domestic banks.

However, Chinn, Dooley, and Shresta (1999) argue that capital flight started to increase after 1993-94 in Korean as well as other Asian countries. The argument on the International Monetary Fund (IMF) reform revealed that moral hazard on the side of lenders was enhanced by the IMF commitment on the lender of last resort. Thus it seems premature to say that one 
should make the most gains from trades by allowing relatively free trade of uninsured transactions by foreign banks with local commitment.

In this context I would like to ask whether capital flight has played an important role in destabilizing the economy. Figure 9.1 demonstrates that portfolio investment continued to increase even in 1997, whereas bank borrowing was reduced after 1997. Does this imply that foreign banks acted as a main conduit of capital flight? We should be cautious, however, about the extremely short-run tradings, notably the derivatives tradings that do not appear in official statistics.

Moreover, my basic question is why foreign banks failed to play a disciplinary role. I believe that financial liberalization in the absence of prudential control, both domestic and international, may result in destabilization of the economy.

The authors argue that the liberalization gain has not been obtained due to the uneven liberalization tilted toward insured agents (domestic banks). However, I would like to ask whether undistorted liberalization can bring about full benefit in the absence of appropriate prudential regulation of financial intermediaries.

From the experience of currency crises, we know that excessive shortterm borrowing tends to make the financial structure fragile to shocks. The paper examines the issue from the borrower's (Korean) perspective. However, the risk-weighting scheme embodied in the Bank for International Settlements (BIS) regulation on international banking favored short-term (less than one year) lending to banks incorporated in the non-OECD member countries (20 percent risk weight), while 100 percent risk weight is attached to longer than one year maturity lending to banks. In contrast, the risk weight is 20 percent in the case of lending to banks incorporated in the OECD member countries. Thus it is not excluded that the combination of uneven liberalization on the side of the borrowing country with the deficiency of prudential controls on international banking on the side of the lending country may be the source of the failure to realize the full gain arising from liberalization of trade in financial services.

Finally, the authors present the proposition that the implicit insurance by government distorted liberalization process. Yet the proposition begs further questions: Does it mean that the removal of implicit insurance can stabilize the financial market? How about the role of explicit insurance? Is it different from implicit insurance? More generally speaking, what is the optimal risk-sharing scheme under conditions of uncertainty about contingent liability arising from demand deposit contracts and information asymmetry between lenders and borrowers? Is there a case for an efficient (partial) bankruptcy of banks or the optimal financial crisis, as argued by Allen and Gale (1998)?

Information asymmetry between the regulatory authority and banks points to the importance of self-discipline based on appropriate incentive 
structure among stakeholders to maintain the soundness of bank management. At the same time, it is interesting to observe that the prudential regulation moves toward the direction of strengthening self- and marketdiscipline or the self-regulation in risk management; it attaches importance to the establishment of risk management systems within individual banks as well as self-imposed targets. The supervising authority simply checks and approves at each stage of decision-making. The regulation under the information asymmetry becomes more efficient by strengthening self-discipline rather than relying on the discretionary discipline imposed by the authority.

Although we admit that the current BIS regulation is deficient in many respects, it works to make the domestic prudential regulation more efficient to the extent that the best practice embodied in the "core principles" of the BIS promotes the self- and market discipline. Although it is commonly observed among different countries that financial liberalization lacking appropriate international rules and efficient domestic regulation has destabilized the economy, efficient domestic regulation mediated through the implementation of the best practice as common knowledge for borrowing and lending countries may promote liberalization in service trade. The role of the international rules combined with efficient domestic regulation provides useful lessons for the liberalization process in other service sectors.

\section{References}

Allen, F., and D. Gale. 1998. Optimal financial crisis. Journal of Finance 53 (4): $1245-84$.

Chinn, M. D., M. P. Dooley and S. Shresta. 1999. Latin America and East Asia in the context of an insurance model of currency crisis. Journal of International Money and Finance 18:659-82. 